Arch. histol. jap., Vol. 42, No. 3 (1979)

p. $197-200$

\title{
In memoriam \\ Wolfgang BARGMANN (1906-1978)
}

\author{
Yutaka SANo
}

On June 20, 1978, Wolfgang Bargmann, Professor emeritus of Kiel University and Chairman of the Department of Anatomy from 1946 to 1974, died at the age of seventy-two from cerebral hemorrhage. His name was well known to anatomists and biologists worldwide, not only for his outstanding accomplishments in the field of neurosecretion but also as the editor of Cell and Tissue Research (formerly Zeitschrift für Zellforschung und mikroskopische Anatomie) and Handbuch der mikroskopischen Anatomie des Menschen, and as the author of the well-known textbook, Histologie und mikroskopische Anatomie des Menschen.

As many as ten Japanese researchers, myself included, have, at one time or another, studied under him in Germany. He also had many friends and acquaintances in Japan through his three visits to Japan, including the 15th General Assembly of the Japan Medical Congress in 1959. So the news of his death came as a shock to many Japanese researchers.

Prof. BARGMAnN was born in Nuremberg on January 27, 1906. After graduating from Lessing Gymnasium for Humanistic Studies in Frankfurt-on-Main in 1926, he studied medicine at Universities in Frankfurt-on-Main, Munich, Vienna and Berlin. He received his doctor's degree in 1932 from Frankfurt University for his work on histology of renal glomerulus, and became an instructor there.

He worked at Frankfurt University for only a year, but it was here that he came to know Ernst Scharrer, who was then head of Ludwig Edinger Institute of Neurology, which was a part of the Department of Pathology at the University. This meeting led, years later, to Prof. BARGMAnN's brilliant work on neurosecretion. At the time, SchARRER was energetically studying the large nerve cells of the nucleus preopticus of teleosts. He had previously found that those cells contained numerous vacuoles and particles that could be stained with various dyes, and thought these represented neurosecretion. Prof. BARGMANN later wrote in reminiscence that on several occasions SchARRER showed him his beautiful histologic preparations, which became firmly imprinted on his mind.

In 1934 he went to Freiburg University, and when the chairman, Professor von Möllendorff, moved to Zurich, Prof. Bargmann went with him to become a Privatdozent. There he was given a chance to write on endocrine organs other than the hypophysis in Histologie und mikroskopische Anatomie des Menschen, of which voN MölLENDORFF was the editor. He wrote chapters on thyroid, parathyroid and Langerhans' islets (1939), and on the thymus and pineal body (1943). After von MöllendorfF's death, Prof. BARgmann took over the editorship. 
His pre-Kiel years were spent in the turmoil of World War II. In 1938 he became a demonstrator (Prosektor) at the Institute of Anatomy in Leipzig, and in 1940 he became Associate Professor there. In 1942 he was appointed Professor at the Institute of Anatomy in Königsberg (now Kaliningrad) in East Prussia. However, the war forced him to suspend his research in the fall of 1944, and in January, 1945, Prof. BARGMANN had to take refuge in Bavaria with only a few instruments for his experiments. Several months later he became Professor at Göttingen University, and on February 28, 1946, he was appointed Chairman of the Department of Anatomy at Kiel University.

In 1975 J. Meits, B. T. Donovan and S. M. McCann edited a book titled Perspectives in Neuroendocrine Research, Vol. I. In the section on "Pioneers in Neuroendocrinology," it contains an essay by Prof. BARGMAnN titled "A Marvelous Region." To those of us who were his students, this little memoir is a vivid reflection of his personality and is a pleasure to read. I would like now to follow this essay and describe how he established the truth of the theory of neurosecretion.

Prof. Bargmann started working on the posterior lobe of the hypophysis in Königsberg, but his work was interrupted by the war and was not resumed until the spring of 1948. At Kiel University he had two able students to work with him. One was Werner CReutzFeldT, who is now Professor of Internal Medicine at Göttingen University, and the other was Walter HiLD, currently Professor of Anatomy at the University of Galveston. He instructed CREuTzFELDT to study the pancreas islet cells of alloxan-induced experimental diabetes, which had been discovered by DUNN and others in England, with chrome-hematoxylin-phloxine stain (Gomori, 1941), and he directed HILD to duplicate ScHARRER's previous work on the preoptic nucleus of lower vertebrates.

After the war Prof. BARgmann received many communications from abroad, which included a letter from ScHARRER. He had emigrated to the United States in 1937 and had been continuing his work on neurosecretion. However, the nature of the secretory granules and where they were released to were still unknown. One day, after a meeting at the University, CREUTzFELDT's father, who was well known for Jakob-Creutzfeldt disease, asked Prof. BARgmann if he really believed in neurosecretion, giving his own opinion that those particles and vacuoles represented only degenerative changes of nerve cells. Prof. Bargmann replied that, having seen SchARRER's specimens, he could not believe them to be pathological changes. $\mathrm{He}$ further speculated that, using Gomori's chrome-hematoxylin-phloxine stain which the younger CREUTZFELDT was using at the time on the pancreas islet cells, he might be able to differentiate types of cells as in $\alpha$-cells and $\beta$-cells of the pancreas islets. He then instructed his technician, Miss JАСOB, to stain a slide of the hypothalamushypophysis of a dog with Gomori's method.

The slide showed the posterior lobe of the hypophysis of a dog stained dark blue, so much so that Miss JАСОВ at first took it to be the result of some technical error on her part. However, Prof. BARgmann, coming into the laboratory after a lecture to the students, took one look at the newly-made, still moist slide through the microscope, and at once realized the enormous importance of the finding. In the slide, the supraoptic nucleus and the paraventricular nucleus were as deeply stained as the posterior lobe, and there were axons, also stained dark blue, connecting the nuclei and the posterior lobe. When I went to Germany in 1957 to work with Prof. BargmanN 
at his invitation, I often heard from him and Miss JАСОВ about that glorious day.

Prof. BARGMAnN concluded from this observation that SCHARRER had been right in believing in the existence of neurosecretory cells, and that these cells produce hormone of the posterior lobe, which is transferred through the axons into the posterior lobe, where it is stored until it is released into the blood stream. He thought the material that was dyed so deeply by chrome-hematoxylin must be the hormone itself or its carrier that was bound to the hormone. He made public this bold hypothesis in 1949, when he published his paper "Über die neurosekretorische Verknüpfung von Hypothalamus und Neurohypophyse" (On the Neurosecretory Connection of Hypothalamus and Neurohypophysis) "in Zeitschrift für Zellforschung, of which he was then the sole editor.

After that, most of his research on neurosecretion was done at Kiel University. With the able assistance of such distinguished co-workers as HiLd, ORTMAnN, Kratsch and $Z$ ETLER, there was a rush of papers on the newest findings on neurosecretion. In 1952 Japanese researchers were at last able to read these papers. It was the time when Prof. Bargmann's group was most active. In the following year the first international symposium on neurosecretion was held in Naples.

Prof. BARGMANN's accomplishments helped the restoration of natural science in Germany after World War II. He first rented a part of a factory, and used it as his laboratory. Then he gradually enlarged his laboratory, and researchers began to come from abroad to work under him. In 1956, an electron microscope was brought in. Prof. Bargmann was one of the advocates of electron microscopy in Germany, and urged the importance of ultrastructure research. Electron microscopic studies of the placenta, capillaries, mammary glands and eosinophiles were also an important part of his work.

As with other distinguished scholars, Prof. BARGMANN was obliged to spend more and more time outside the laboratory. He served as President of Kiel University for two terms, 1951-1952 and 1965-1966. He was also busy as Vice Chairman of the German Association of Researchers (Deutsche Forschungsgemeinschaft), as a member of the Senate of the Max-Planck Society (1966-1972), and as a member of many committees for founding new universities. He was awarded the Great Cross of Distinguished Service (Großes Bundesdienstkreuz), and was a member of the Academy of Natural Scientists of Germany (recipient of the Schleiden medal). He was also a member of the Academies of Holland, Sweden, Norway and Finland, and an honorary member of the Anatomical Societies of Japan, the United States, Hungary and Yugoslavia.

I was lucky because, when I went to Germany to work with Prof. BargmanN (1957-1958), he was not yet so busy with his public duties, and I could make experiments under his personal direction. I can still vividly recollect the way he always asked us, "Was gibt es Neues? Was macht die Forschung? (Is there anything n£w? How is your research doing?) When we were not doing our best with our work, his words sounded like a reproach. However, when things were going well, they were words of gentle encouragement. He was good at instructing those who studied under him according to their individual abilities and apptitudes, thus helping them become accomplished scholars. This is reflected in the fact that so many of his students later became professors. Besides being an eminent scholar, he was a versatile writer and wrote essays outside his own field. He was also interested in 
travelling and studying the culture and history of other countries. He loved Kyoto, and it made him happy that I became a professor there.

The study of neurosecretion has been further developed as the study of the peptide neurons, as Prof. Bargmann suggested. The problem of the production and release of neurogenic hormones has come to be pursued along with that of the production and release of the neuronal transmitters. Prof. BARGMAnN gave biological significance to SCHARRER's work, and his work grew with the years, always playing an important part in establishing functional histology. This is why I regard his death as marking the end of an epoch.

In the fall before last my wife and I visited Prof. Bargmann in Kiel. When he came to see us off at the railroad station, he remarked that, had he mastered biochemical and pharmacological techniques in his youth, he would have been able to achieve far more. He expressed the same sentiment at the conclusion of the memoir, "A Marvelous Region." As the time for the train's departure neared, he said goodbye to us and walked away. We will never forget the way he looked back from time to time to wave to us.

On March 13, 1978, only a few months before Prof. Bargmann's death, Miss JAсOB, who had worked with him for so many years as his technical assistant, also died. I would like to conclude his memorial with a prayer for the repose of the souls of Prof. Bargmann and Miss Jacob.

April, 1979

Prof. Yutaka Sano

Department of Anatomy

Kyoto Prefectural University of Medicine

Kyoto, 602 Japan 